\title{
Chromatographic Isolation and Structural Elucidation of Secondary Metabolites from the Soil-Inhabiting Fungus Aspergillus fumigatus 3T-EGY
}

\author{
Mohamed S. Abdel-Aziz ${ }^{1}$, Mosad A. Ghareeb ${ }^{2 *}$, Amal M. Saad ${ }^{2}$, Laila A. Refahy ${ }^{2}$ and Ahmed A. Hamed ${ }^{\mathbf{1}}$ \\ ${ }^{1}$ Microbial Chemistry Department, Genetic Engineering and Biotechnology Division, National Research Center, \\ El-Bohouth Street 33, Dokki-Giza 12622, Egypt \\ ${ }^{2}$ Medicinal Chemistry Department, Theodor Bilharz Research Institute, Kornaish El-Nile, \\ Warrak El-Hadar 12411, Imbaba, Giza, Egypt
}

Received: 18 May 2017; accepted: 05 July 2017

\begin{abstract}
Eight compounds were isolated and identified from the soil-inhabiting fungus Aspergillus fumigatus 3T-EGY, namely, stearic acid (1), $\alpha$-linolenic acid (2), physcion (3), di-(2-ethylhexyl) phthalate (4), 2,4,5,17-tetramethoxy pradimicin lactone (5), 3,5-dihydroxy-7-O- $\alpha$-rhamnopyranoyl-2 $H$-chromen-2-one (6), juglanthraquinone A-5-O-D-rhodosamine$\left(4^{\prime} \rightarrow 1^{\prime \prime}\right)$-2-deoxy-D-glucose ( $\left.4^{\prime \prime} \rightarrow 1^{\prime \prime \prime}\right)$-cinerulose B (7), and micropeptin (8). Their structures were determined on the basis of one-dimensional (1D-) and two-dimensional nuclear magnetic resonance (2D-NMR) $\left[{ }^{1} \mathrm{H}-,{ }^{13} \mathrm{C}-\mathrm{NMR},{ }^{1} \mathrm{H}-{ }^{1} \mathrm{H}\right.$ COSY (COrrelated SpectroscopY), and ${ }^{1} \mathrm{H}_{-}{ }^{13} \mathrm{C}$ HMBC (Heteronuclear Multiple Bond Correlation) spectroscopy]. Compound 7 showed moderate in vitro antimicrobial activity against three pathogenic strains with inhibition zones values were ranged from 9.0 to $10.66 \mathrm{~mm}$ compared to neomycin as a positive control with inhibition zones values were ranged from 14.0 to $19.0 \mathrm{~mm}$.
\end{abstract}

Keywords: Aspergillus fumigatus 3T-EGY, phenolics, juglanthraquinone A triglycoside, VLC, in vitro antimicrobial activity

\section{Introduction}

Microbial secondary metabolites have low molecular weight, and they are not important for their growth and reproduction as well as cell growth [1]. Berdy (2005) reported that the largest microbial group producing bioactive secondary metabolites was filamentous bacteria (actinomycetes), representing about $45 \%$ of the total compounds discovered followed by fungi (38\%), but unicellular bacteria possess about $17 \%$ only [2]. Fungi are common in nature and are considered as a fruitful source of many antibiotics [3, 4]. Fungi related to as comycetes like Aspergillus, Penicillium, and Fusarium are the most famous producers of biologically active secondary metabolites in comparison to other fungal genera [2]. The majority of soil fungi were known for their potentiality to decompose organic matters and their contribution to nutrient cycling. In addition, they were considered as promising bioactive secondary metabolites producers as they have produced many bioactive compounds and chemically exceptional skeletal structures used as pharmaceuticals [5]. Recently, fungi have appeared as novel sources of antioxidants as a part of their bioactive secondary metabolites [6,7]. Fungi are obviously a varied group having about 1.5 million species, which can give a broad diversity of metabolites such as alkaloids, benzoquinones, flavonoids, phenols, steroids, terpenoids, tetralones, and xanthones [8]. In addition to antioxidants, fungi exhibit various bioactivities and functions. Fungi found different applications in medicine industry and considered to be possible sources of new therapeutic agents. Therefore, the aims of the current study were to isolate, identify the fungus, and evaluate the in vitro antimicrobial activity of different vacuum liquid chromatography (VLC) fractions from extract of the fungus Aspergillus fumigatus 3T-EGY, grown on rice medium. The chromatographic isolation and identification of its bioactive secondary metabolites were also studied.

* Author for correspondence: m.ghareeb@tbri.gov.eg

\section{Experimental}

General Experimental Procedures. Melting point (uncorrected) was determined on an electrothermal apparatus. ${ }^{1} \mathrm{H}$-, ${ }^{13} \mathrm{C}-\mathrm{NMR},{ }^{1} \mathrm{H}-{ }^{1} \mathrm{H}$ COSY (COrrelated SpectroscopY), and ${ }^{1} \mathrm{H}-{ }^{13} \mathrm{C}$ HMBC (Heteronuclear Multiple Bond Correlation) spectra were obtained using a pulse sequence supplied from Varian Mecauy $300 \mathrm{MHz}$ spectrometer $\left({ }^{1} \mathrm{H}, 300 \mathrm{MHz}\right.$ and ${ }^{13} \mathrm{C}, 75 \mathrm{MHz}$, in deuterated dimethylsulphoxide [DMSO- $\left.\left.d_{6}\right]\right)$. Chemical shifts $(\delta)$ were given in values (ppm) relative to trimethylsilane (TMS) as an internal reference and coupling constant $(J)$ in Hertz. All solvents and reagents used were of analytical grade. Sephadex LH-20 (25-100 $\mu \mathrm{m}$, Pharmacia Fine Chemicals Inc., Uppsala, Sweden). Paper chromatography (PC) was carried out on Whatman No. 1 paper sheets $(57 \mathrm{~cm} \times 46 \mathrm{~cm}$; Maidstone, England) $\left(\mathrm{S}_{1}, n-\mathrm{BuOH}-\mathrm{AcOH}-\mathrm{H}_{2} \mathrm{O}, 4: 1: 5\right.$ upper layer; $\mathrm{S}_{2}, \mathrm{H}_{2} \mathrm{O}-$ $\mathrm{AcOH}, 85: 15)$. Spots were visualized under Vilber Lourmat UV lamp (VL-6LC France) at 254 and $365 \mathrm{~nm}$ and then sprayed with methanolic $1 \% \mathrm{FeCl}_{3}$ and/or $5 \% \mathrm{AlCl}_{3}$.

Media. The following media were used in the study: nutrient agar medium (DSMZ1) (beef extract, 3; peptone, 10; agar, 18-20; distilled water, $1000 \mathrm{~mL}$; pH 7), Czapek-Dox (CD) agar medium (DSMZ 130) (sucrose, 30; $\mathrm{NaNO}_{3}, 3$; $\mathrm{MgSO}_{4} \cdot 7 \mathrm{H}_{2} \mathrm{O}, 0.5 ; \mathrm{FeSO}_{4} \cdot 7 \mathrm{H}_{2} \mathrm{O}, 0.01 ; \mathrm{K}_{2} \mathrm{HPO}_{4}, 1 ; \mathrm{KCl}, 0.5$; distilled water, $1000 \mathrm{~mL}$; agar, 18-20).

Isolation of Terrestrial Fungi. Soil samples were collected in the surrounding of Mansoura Governorate, Egypt during May 2012; soil was taken at $10 \mathrm{~cm}$ depth. Samples were sieved and air dried for 3-5 days at $28{ }^{\circ} \mathrm{C}$. After drying, samples were kept at $10{ }^{\circ} \mathrm{C}$ until used. Fungal strains were isolated from soil samples. Enumeration of the microbes present in the soil was done by serial dilution-agar plating method. Serial dilution of soil suspension was prepared up to $10^{-6}$ dilution. Then, $0.1 \mathrm{~mL}$ of suspension from dilutions $10^{-3}$ to $10^{-6}$ was transferred to the petri dishes containing $\mathrm{CD}$ agar medium at $28 \pm 2{ }^{\circ} \mathrm{C}$ for 6-8 days, and growth was observed after 2 days. The fungi

This is an open-access article distributed under the terms of the Creative Commons Attribution-NonCommercial 4.0 International License (https://creativecommons.org/licenses/by-nc/4.0/), which permits unrestricted use, distribution, and reproduction in any medium for non-commercial purposes, provided the original author and source are credited, a link to the CC License is provided, and changes - if any - are indicated. 
isolated on culture medium from soil were purified by spore suspension and streak method. The cultures were routinely transferred (every 6-8 days) onto fresh $\mathrm{CD}$ agar plates by streaking. Before fungal cultures were used for inoculation of liquid growth medium, the fungus was subjected to three transfers on CD agar plates by the direct agar transfer method [9].

Scale up Fermentation, and Extraction. Scale-up fermentation has been maintained using 15 Erlenmeyer flasks (1 L volume); each contains $100 \mathrm{~g}$ rice and $100 \mathrm{~mL}$ distilled water, sterilized at $121{ }^{\circ} \mathrm{C}(15 \mathrm{lb})$ for $20 \mathrm{~min}$. Each flask was inoculated with spore suspension from 1 slant (10 days old). After incubation at $30{ }^{\circ} \mathrm{C}$ for 15 days, the medium was extracted with ethyl acetate several times till exhaustion. A reddish brown extract was produced $(\cong 20 \mathrm{~g})$.

Fungal Identification. Fungal isolate (3T) was identified by DNA isolation, amplification by polymerase chain reaction (PCR), and sequencing of the internal transcribed spacer (ITS) region. The primers ITS2 (GCTGCGTTCTTCATCGATGC) and ITS3 (GCATCGATGAAGAACGCAGC) were used for PCR amplification while ITS1 (TCCGTAGGTGAACCTGCGG) and ITS4 (TCCTCCGCTTATTGATATGC) were taken for sequencing. Candida sp. was tested as control. The sequence data were submitted to GenBank. The fungal strain (3T) culture was reserved in the Microbial Chemistry Department Culture Collection of Microorganisms.

In vitro Antimicrobial Activity. Disc agar plate method has been established to evaluate the antimicrobial activities of different fractions as well as compound 7 that dissolved in methanol $(\mathrm{MeOH})$ [10]. Four different test microbes, Staphylococcus aureus, Escherichia coli, Candida albicans, and Aspergillus niger, were selected to evaluate the antimicrobial activities as representatives of Gram+ bacteria, Gram- bacteria, yeast, and fungal groups, respectively. The bacterial and yeast test microbes were grown on a nutrient agar medium. On the other hand, the fungal test microbe was cultivated on CzapekDox medium. The culture of each test microbe was diluted by distilled water (sterilized) to $10^{7}$ to $10^{8}$ colony forming units (CFUs) $/ \mathrm{mL}$, and then $1 \mathrm{~mL}$ of each was used to inoculate $1 \mathrm{~L}$ Erlenmeyer flask containing $250 \mathrm{~mL}$ of solidified agar media. These media were put onto previously sterilized Petri dishes (10 cm diameter having $25 \mathrm{~mL}$ of solidified media). Filter paper discs ( $5 \mathrm{~mm} \varnothing$, Whatman No. 1 filter paper) loaded with $0.2 \mathrm{mg}$ of each extract and $100 \mu \mathrm{g}$ of pure sample. The discs were dried at room temperature under sterilized conditions. The paper discs were placed on agar plates seeded with test microbes and incubated for $24 \mathrm{~h}$, at the appropriate temperature of each test organism. Antimicrobial activities were recorded as the diameter of the clear zones (including the disc itself) that appeared around the discs [11].

Isolation and Purification of Secondary Metabolites. The ethyl acetate (EtOAc) extract was evaporated to dryness to give a brownish mass $(20 \mathrm{~g})$ and then underwent fractionation using VLC on silica gel 60 using solvents in a gradient of increasing polarity; $n$-hexane-ethyl acetate, dichloromethane-methanol $\left(\mathrm{CH}_{2} \mathrm{Cl}_{2}-\mathrm{MeOH}\right)$, and $100 \%$ acetone step gradient elution to afford thirteen fractions eluted from the VLC as follows: fractions $1-6$ were eluted by $n$-hexane-EtOAc; 100:0-80:20 60:40-40:60-20:80-80:20-0:100 (\%v/v), respectively, for the fractions 1-6; also, fractions 7-12 were eluted by $\mathrm{CH}_{2} \mathrm{Cl}_{2}-$ $\mathrm{MeOH} ; \quad 100: 0-80: 20-60: 40-40: 60-20: 80-80: 20-0: 100$ (\%v/v), respectively, for the fractions $7-12$, finally fraction (13) was eluted by $100 \%$ acetone. The in vitro antimicrobial activity of these fractions was evaluated; among them, the most promising fraction was undergoing further chromatographic isolation and purification via size exclusion chromatography using Sephadex LH-20 column $(30 \times 2 \mathrm{~cm})$ eluted with $100 \% \mathrm{MeOH}$ to afford eight pure compounds (Figure 1). In details, fraction 3 (1.5 g) was subjected to Sephadex LH-20 eluted with gradient mix elution system, $\mathrm{CH}_{2} \mathrm{Cl}_{2}-\mathrm{MeOH}$ till $100 \% \mathrm{MeOH}$; each subfraction was eluted as a single band to afford four compounds 1-4. On the other hand, fraction 4 (1.25 g) was subjected to Sephadex LH-20 column eluted with $100 \% \mathrm{MeOH}$ to afford two compounds 5 and 6. Also, fraction $5(1 \mathrm{~g})$ was subjected to Sephadex LH-20 column eluted with $100 \% \mathrm{MeOH}$ to afford compound 7. Finally, fraction $6(0.75 \mathrm{~g})$ was subjected to Sephadex LH-20 column eluted with $100 \% \mathrm{MeOH}$ to afford compound 8 .

\section{Results and Discussions}

Identification of the Fungal Isolate 3T-EGY. Basic Local Alignment Search Tool (BLAST) search for the fungus isolate revealed $99 \%$ similarity to A. fumigatus. The phylogenic tree of this fungal isolate was also constructed (Figure 2). Based on the above identification techniques, our local soil fungal isolate was identified as A. fumigatus 3T-EGY with the GeneBank accession number KP140961 (http://www.ncbi.nlm.nih.gov/nuccore/ KP140961.1). Conventional fungal identification protocols including morphological characteristics, growth on different media, and type of spores as well as biochemical behavior such as pigment production, etc. have been commonly applied, and several new species still now are identified according to this methods [12]. However, these methods take long time, have low

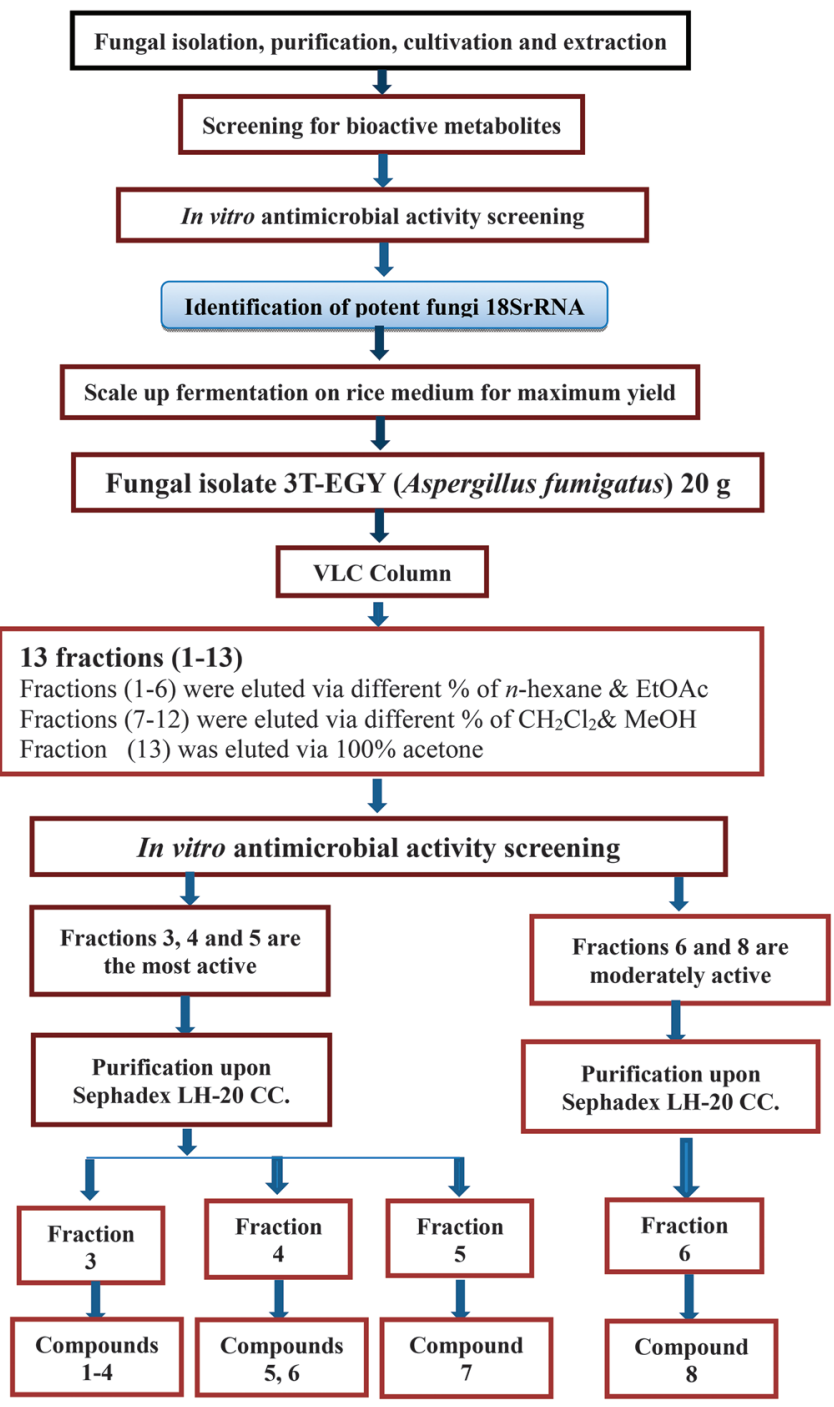

Figure 1. Flow chart representing the cultivation, extraction, and purification of bioactive metabolites from fungus Aspergillus fumigatus 3T-EGY 


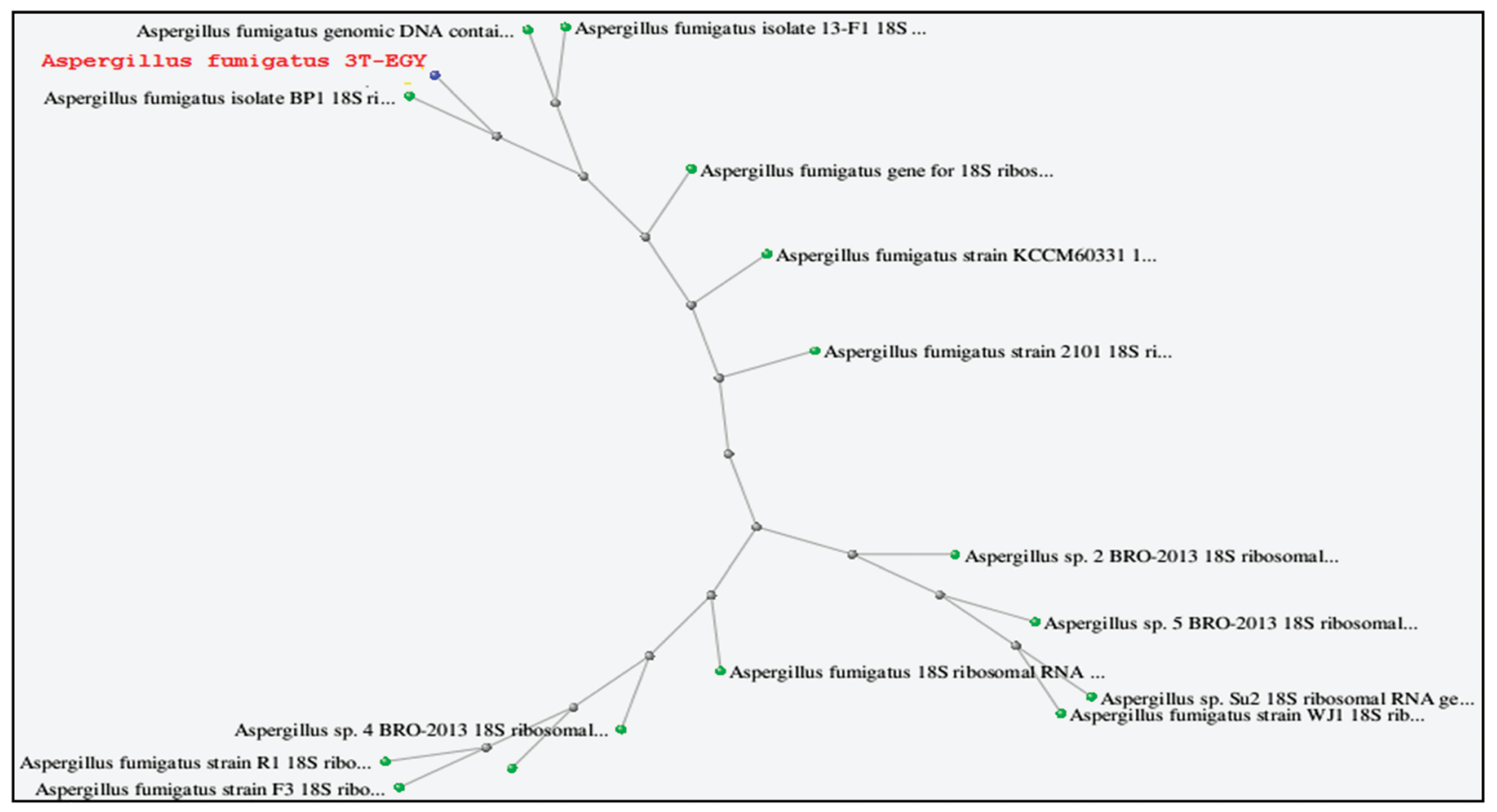

Figure 2. The phylogenetic tree of Aspergillus fumigatus 3T-EGY isolated from soil

sensitivity, difficult to control, and non-specific [13, 14]. Targeting specific regions within the ribosomal RNA gene clusters using universal primers through PCR amplification is another optional method for the fungal identification to the species level and also for analyzing fungal diversity [15]. In this context, internal transcribed spacer (ITS) regions (ITS-1 to ITS-5) of ribosomal DNA (rDNA) gene clusters are used. Primers routinely used for the amplification of ITS regions of ribosomal DNA are ITS-1 and ITS-4 [16].

In vitro Antimicrobial Activity of the Fungal Extract and Resulting Fractions (1-13) from VLC Column. The in vitro antimicrobial activity of the soil inhabiting fungus extract was evaluated against four pathogenic microbial strains, i.e., $S$. aureus, Pseudomonas aeruginosa, C. albicans, and A. niger. The results revealed that the extract showed strong activity against $P$. aeruginosa and $C$. albicans with equal inhibition zones of $15 \mathrm{~mm}$, and it was also showed a moderate activity against $S$. aureus and $A$. niger with inhibition zones of 10 and $9 \mathrm{~mm}$, respectively. Penicillin $\mathrm{G}$ was used as positive control at concentration of $100 \mu \mathrm{g} /$ disc with inhibition zones (S. aureus, $27 \mathrm{~mm}$; P. aeruginosa, $20 \mathrm{~mm}$; C. albicans, $25 \mathrm{~mm}$; and A. niger, $0 \mathrm{~mm}$ ) (Table 1). On the other hand, the resulting fractions (1-13) from the VLC column of the ethyl acetate extract were subjected to in vitro antimicrobial screening. Fractions 3, 4, and 5 exhibited the highest antimicrobial activity against all test microbes with inhibition zones were ranged from 8.0 to $18.5 \mathrm{~mm}$. Moreover, fractions 6 and 8 showed a moderate activity with inhibition zones were ranged from 8.0 to $18.5 \mathrm{~mm}$. Furthermore, fraction 7 showed a weak activity against only two test microbes, $P$. aeruginosa $(6.5 \mathrm{~mm})$ and $C$. albicans $(6 \mathrm{~mm})$.

Table 1. In vitro antimicrobial activity of the ethyl acetate extract of Aspergillus fumigatus 3T-EGY grown on rice medium

\begin{tabular}{lccc}
\hline Test microbe & Microbial group & \multicolumn{2}{c}{ Clear zone $(\phi \mathrm{mm})^{a}$} \\
\cline { 3 - 4 } & & 3T-EGY & Penicillin $\mathrm{G}^{b}$ \\
\hline S. aureus & $\mathrm{G}+$ bacteria & 10 & 27 \\
P. aeruginosa & G- bacteria & 15 & 20 \\
C. albicans & Yeast & 15 & 25 \\
A. niger & Fungus & 9 & 0
\end{tabular}

${ }^{a}$ Inhibition zones diameter ( $\left.\mathrm{mm}\right)$.

${ }^{b}$ Penicillin G was used as a positive control $(100 \mu \mathrm{g} / \mathrm{disc})$.
In addition, there is no any activity recorded with fractions 1,2 , 9, 10, 11, 12, and 13 (Table 2).

Reviewing the literature, it was revealed that the endophytic isolate A. fumigatus $\mathrm{R} 7$ exhibited strong in vitro antibacterial activity against Gram $+B$. subtilis $(16 \mathrm{~mm})$ and $S$. aureus $(15 \mathrm{~mm})$, and Gram- bacteria $P$. aeruginosa $(19 \mathrm{~mm})$ and E. coli $(16 \mathrm{~mm})$, and there is no any antifungal activity against $A$. niger, A. flavus, and C. albicans [17]. Accordingly, our results are in agreement with the finding of previous studies. Also, the crude extract of A. fumigatus BTMF9 exhibited in vitro antimicrobial activity against Gram-positive bacteria $B$. circulans [18].

Structure Elucidation. The promising resulting fractions from VLC column which underwent further purification upon Sephadex LH-20 column to afford eight pure isolates, these compounds were identified on the basis of their onedimensional (1D-) and two-dimensional nuclear magnetic resonance (2D-NMR) $\left[{ }^{1} \mathrm{H}-,{ }^{13} \mathrm{C}-\mathrm{NMR},{ }^{1} \mathrm{H}_{-}{ }^{1} \mathrm{H}\right.$ COSY, and ${ }^{1} \mathrm{H}-{ }^{13} \mathrm{C}$ HMBC analyses] (Figure 3).

Table 2. In vitro antimicrobial activity of the different fractions from VLC column of ethyl acetate extract of Aspergillus fumigatus 3T-EGY grown on rice medium

\begin{tabular}{|c|c|c|c|c|}
\hline \multirow[t]{2}{*}{ Fraction no. } & \multicolumn{4}{|c|}{ Clear zone $(\phi \mathrm{mm})^{a}$} \\
\hline & S. aureus & P. aeruginosa & C. albicans & A. niger \\
\hline 1 & 0 & 0 & 0 & 0 \\
\hline 2 & 0 & 0 & 0 & 0 \\
\hline 3 & $11.50 \pm 0.70^{b}$ & $14.50 \pm 0.65$ & $13.50 \pm 0.75$ & $8.50 \pm 0.80$ \\
\hline 4 & $14.0 \pm 1.41$ & $16.0 \pm 0.75$ & $18.50 \pm 2.12$ & $9.50 \pm 0.90$ \\
\hline 5 & $11.50 \pm 1.21$ & $10.0 \pm 2.15$ & $9.50 \pm 1.30$ & $8.0 \pm 1.23$ \\
\hline 6 & $6.50 \pm 0.72$ & $6.50 \pm 0.84$ & $6.0 \pm 0.0$ & $9.0 \pm 1.43$ \\
\hline 7 & $0.0-0.0$ & $8.50 \pm 0.79$ & $6.0 \pm 0.0$ & $0.0-0.0$ \\
\hline 8 & $6.50 \pm 0.92$ & 0 & $6.50 \pm 1.45$ & $12.0 \pm 1.25$ \\
\hline 9 & 0 & 0 & 0 & 0 \\
\hline 10 & 0 & 0 & 0 & 0 \\
\hline 11 & 0 & 0 & 0 & 0 \\
\hline 12 & 0 & 0 & 0 & 0 \\
\hline 13 & 0 & 0 & 0 & 0 \\
\hline Penicillin $\mathrm{G}^{c}$ & 27 & 20 & 25 & 0 \\
\hline Streptomycin $^{d}$ & 13 & 21 & 0 & 0 \\
\hline $\begin{array}{l}{ }^{a} \text { Inhibition z } \\
{ }^{b} \text { Mean } \pm \text { SD } \\
{ }^{c} \text { Penicillin G } \\
{ }^{d} \text { Streptomyc }\end{array}$ & $\begin{array}{l}n=3 \text {. } \\
n=8 \text { diameter } \\
\text { was used as a } \\
n \text { was used as }\end{array}$ & $\begin{array}{l}\mathrm{nm}) \\
\text { ositive control } \\
\text { positive contro }\end{array}$ & $\begin{array}{l}(100 \mu \mathrm{g} / \mathrm{disc}) \\
1(100 \mu \mathrm{g} / \mathrm{disc})\end{array}$ & \\
\hline
\end{tabular}


Compound 1 was isolated as light yellow wax, infrared (IR): $\lambda_{\max }\left(\mathrm{cm}^{-1}\right): 722,787,1075,1170,1225,1380,1470,1550$, 1682 (carbonyl group), 1730, 2975 (CH-aliphatic), and 3475 (hydroxyl group). ${ }^{1} \mathrm{H}-\mathrm{NMR}$ (300 MHz, DMSO- $d_{6}$ ) spectrum showed a broad singlet signal observed at $\delta_{\mathrm{H}} 0.78 \mathrm{ppm}$ which indicated aliphatic methyl group. A large singlet appeared at $\delta_{\mathrm{C}} 1.33 \mathrm{ppm}$ indicative for thirty protons of fifteen consecutive methylene groups. A broad singlet signal appeared at $\delta_{\mathrm{H}} 2.46 \mathrm{ppm}(2 \mathrm{H}, \mathrm{br} \mathrm{s}, \mathrm{H}-2)$ of methylene group vicinal to carboxyl group. ${ }^{13} \mathrm{C}-\mathrm{NMR}\left(75 \mathrm{MHz}, \mathrm{DMSO}-d_{6}\right)$ spectra showed peaks at $\delta_{\mathrm{C}} 175.01 \mathrm{ppm}(\mathrm{C}-1)$ indicative to carbonyl group of carboxylic acid and at $\delta_{\mathrm{C}} 39.33 \mathrm{ppm}(\mathrm{C}-2)$ indicative to oxy methylene group. The consecutive methylenes were detected at $\delta_{\mathrm{C}} 25.02$ (C-3), 29.17-29.67 (C-4 \& C-15), 34.15 (C-16), and $22.65(\mathrm{C}-17)$; the last free methyl group appeared at $\delta_{\mathrm{C}} 14.31$ (C-18) ppm. All peaks in the ${ }^{1} \mathrm{H}$ - and ${ }^{13} \mathrm{C}-\mathrm{NMR}$ spectrum exist in aliphatic region, and this is an indication for aliphatic nature of compound 1. According to previous data and via comparison with physical and spectral data from the literature [19-21], compound 1 was identified as stearic acid.
Compound 2 was obtained as a light yellow wax; the IR spectrum showed a broad band at $3410.26 \mathrm{~cm}^{-1}$ and $1716.70 \mathrm{~cm}^{-1}$, indicating the presence of $\mathrm{OH}$ group and a carbonyl $(\mathrm{C}=\mathrm{O})$ group, and also showed peaks at $2929.97 \mathrm{~cm}^{-1}$, $1458.23 \mathrm{~cm}^{-1}$, and $1408.08 \mathrm{~cm}^{-1}$ indicating the presence of aliphatic bonds. The ${ }^{1} \mathrm{H}-\mathrm{NMR}$ spectrum showed a characteristic signal at $\delta_{\mathrm{H}} 0.81 \mathrm{ppm}(3 \mathrm{H}, \mathrm{s}, \mathrm{Me}-18)$ for methyl group and multiplets at $\delta_{\mathrm{C}} 1.33-1.61 \mathrm{ppm}$ (methylene hump) for 20 aliphatic protons, and at $\delta_{\mathrm{H}} 2.13 \mathrm{ppm}(2 \mathrm{H}, \mathrm{t}, J=7.2 \mathrm{~Hz}, \mathrm{H}-2)$, $\delta_{\mathrm{H}} 2.46 \mathrm{ppm}(4 \mathrm{H}, \mathrm{H}-8$, and $\mathrm{H}-17)$, and $\delta_{\mathrm{H}} 2.22 \mathrm{ppm}(2 \mathrm{H}, \mathrm{t}$, $J=7.2 \mathrm{~Hz}, \mathrm{H}-14)$, it also showed broad multiple peaks at $\delta_{\mathrm{H}} 4.99-5.29 \mathrm{ppm}$ for olefinic protons. Furthermore, ${ }^{13} \mathrm{C}-\mathrm{NMR}$ spectrum showed a peak at $\delta_{\mathrm{C}} 170 \mathrm{ppm}$ indicating the presence of carbonyl $(-\mathrm{C}=\mathrm{O})$ carbon and peaks at $\delta_{\mathrm{C}} 130.22$ and $128.27 \mathrm{ppm}$ for four olefinic carbons. All the previous data coincide with the spectral data of $\alpha$-linolenic acid which was previously isolated from Rhodiola rosea [22, 23]. Therefore, compound 2 was identified as $\alpha$-linolenic acid.

Compound 3 was obtained as orange crystal (m.p. 208$210^{\circ} \mathrm{C} ; R_{\mathrm{f}}$ upon $\mathrm{PC}$ in $15 \% \mathrm{AcOH}(0.05)$ \& BAW (0.87) and<smiles>CC/C=C\C/C=C\C/C=C\CCCCCCCC(=O)O</smiles>

1

2

3

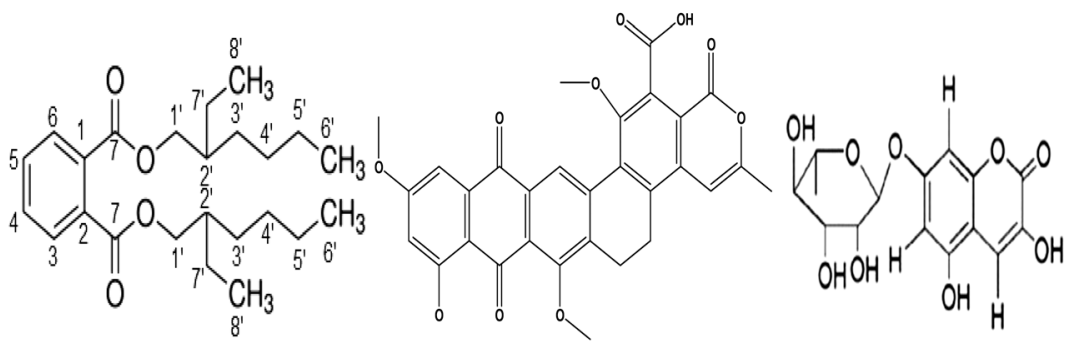

4

5

6

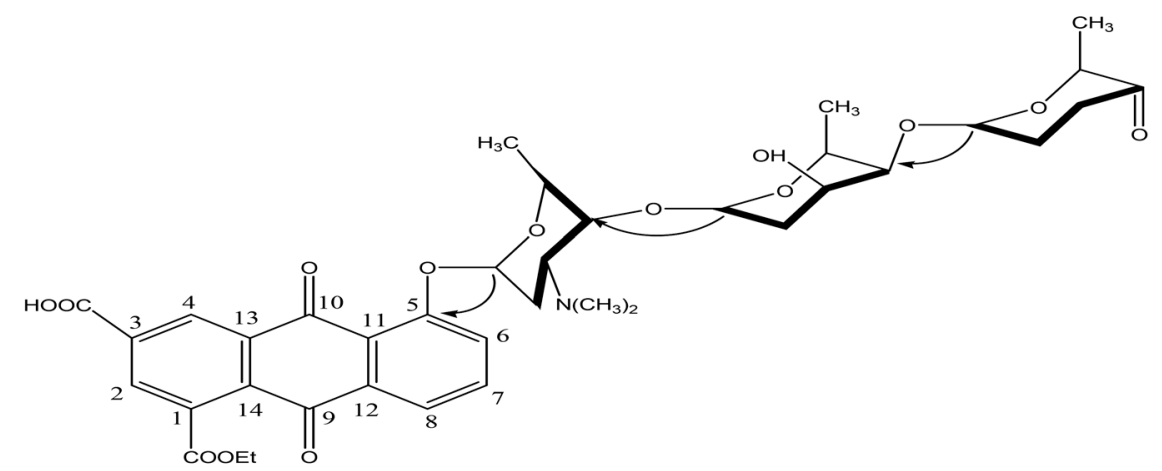

7

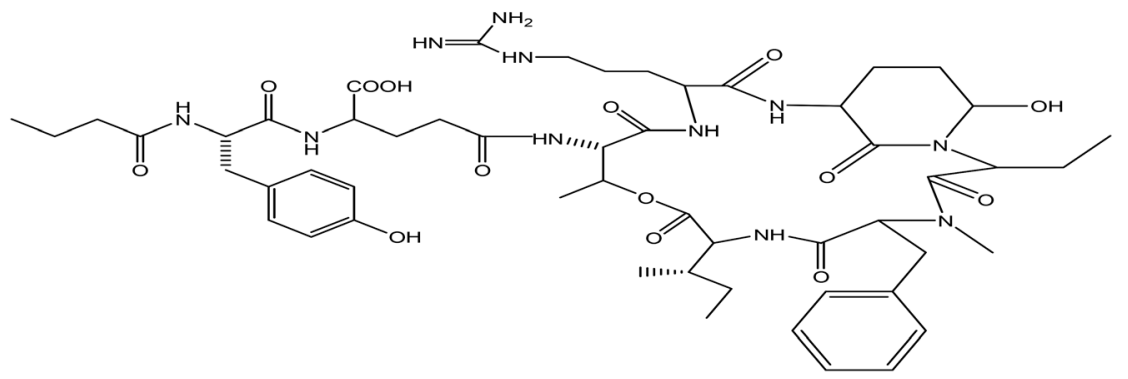

8

Figure 3. Chemical structures of the isolated compounds from Aspergillus fumigatus 3T-EGY 
upon TLC in $\mathrm{CH}_{2} \mathrm{Cl}_{2}-\mathrm{MeOH}$, 9:1 (0.76)). ${ }^{1} \mathrm{H}-\mathrm{NMR}$ spectrum showed signals in aromatic region at $\delta_{\mathrm{H}} 6.75 \mathrm{ppm}(1 \mathrm{H}$, br s, H-7), $\delta_{\mathrm{H}} 7.06 \mathrm{ppm}\left(1 \mathrm{H}\right.$, br s, H-2), $\delta_{\mathrm{H}} 7.36 \mathrm{ppm}(1 \mathrm{H}, \mathrm{d}$, $J=2.5 \mathrm{~Hz}, \mathrm{H}-5)$, and $\delta_{\mathrm{H}} 7.66 \mathrm{ppm}(1 \mathrm{H}, \mathrm{d}, J=2.5 \mathrm{~Hz}, \mathrm{H}-4)$, it also showed two singlets at $\delta_{\mathrm{H}} 2.46 \mathrm{ppm}(3 \mathrm{H}, \mathrm{s}, \mathrm{Me})$ and $\delta_{\mathrm{H}} 3.84 \mathrm{ppm}(3 \mathrm{H}, \mathrm{s}, \mathrm{O}-\mathrm{Me})$, and a characteristic signal at $\delta_{\mathrm{H}} 13.29 \mathrm{ppm}$ for hydroxyl groups. These data agreed with ${ }^{13} \mathrm{C}$-NMR spectra which showed sixteen carbons; among them, fourteen carbons appeared in the aromatic region and two carbons showed signals at $\delta_{\mathrm{C}} 21.8(\mathrm{Me})$ and $\delta_{\mathrm{C}} 56.7 \mathrm{ppm}(\mathrm{OMe})$. The above mentioned spectral data agree with that reported in literature for physcion from genus Aspergillus [24, 25], lichen Xanthoria [26], and higher plant species [27]. Moreover, physcion has been widely isolated and characterized from both terrestrial and marine sources $[24,28]$. Therefore, compound 3 was identified as physcion (1,8-Dihydroxy-3-methoxy-6-methylanthraquinone or Emodin-3-methyl ether).

Compound 4 was obtained as very light yellow oil, dissolved in most organic solvents but insoluble in water $\left(R_{\mathrm{f}} 0.58\right.$ upon TLC $\left[n\right.$-hexane- $\left.\mathrm{CH}_{2} \mathrm{Cl}_{2} ; 8: 2, \mathrm{v} / \mathrm{v}\right], 0.66$ [ $n$-hexane-ethyl acetate; 8.5:1.5, v/v]). It gave purple color with concentrated $\mathrm{H}_{2} \mathrm{SO}_{4}$. The IR spectrum showed a characteristic carbonyl band at $1655 \mathrm{~cm}^{-1}$, aromatic $\left(\right.$ Ar-C-H) at $3050 \mathrm{~cm}^{-1}$, aliphatic $(-\mathrm{C}-\mathrm{H})$ band at $2932 \mathrm{~cm}^{-1}$, strong band for etheric bond $(-\mathrm{C}-\mathrm{O})$ at $1021 \mathrm{~cm}^{-1}$, and methyl vibration band from 1410 to $1319 \mathrm{~cm}^{-1}$. ${ }^{1} \mathrm{H}-\mathrm{NMR}\left(300 \mathrm{MHz}, \mathrm{DMSO}-d_{6}\right): \delta_{\mathrm{H}} 7.67(2 \mathrm{H}, \mathrm{dd}, J=6 \mathrm{~Hz}$, $2.7 \mathrm{~Hz}, \mathrm{H}-3, \mathrm{H}-6), \delta_{\mathrm{H}} 7.59$ (2H, dd, $\left.J=6 \mathrm{~Hz}, 2.7 \mathrm{~Hz}, \mathrm{H}-4, \mathrm{H}-5\right)$, $\delta_{\mathrm{H}} 4.12\left(4 \mathrm{H}, \mathrm{m}, \mathrm{H}-1^{\prime}\right), \delta_{\mathrm{H}} 1.60\left(2 \mathrm{H}, \mathrm{m}, \mathrm{H}-2^{\prime}\right), \delta_{\mathrm{H}} 1.21-1.33(12 \mathrm{H}$, m, H-3'-H-4', H-5'), $\delta_{\mathrm{H}} 0.88\left(6 \mathrm{H}, \mathrm{t}, J=5.7 \mathrm{~Hz}, \mathrm{H}-6^{\prime}\right), \delta_{\mathrm{H}}$ $1.49\left(4 \mathrm{H}, \mathrm{m}, \mathrm{H}-7^{\prime}\right), \delta_{\mathrm{H}} 0.80\left(6 \mathrm{H}, \mathrm{t}, J=5.1 \mathrm{~Hz}, \mathrm{H}-8^{\prime}\right) .{ }^{13} \mathrm{C}-\mathrm{NMR}$ $\left(75 \mathrm{MHz}, \mathrm{DMSO}-d_{6}\right): \delta_{\mathrm{C}} 166.7(-\mathrm{C}=\mathrm{O}), \delta_{\mathrm{C}} 131.8(\mathrm{C}-1, \mathrm{C}-2)$, $\delta_{\mathrm{C}} 131.1(\mathrm{C}-3, \mathrm{C}-6), \delta_{\mathrm{C}} 129.3(\mathrm{C}-4, \mathrm{C}-5), \delta_{\mathrm{C}} 67.2\left(\mathrm{C}-1^{\prime}\right)$, $\delta_{\mathrm{C}} 38.2\left(\mathrm{C}-2^{\prime}\right), \delta_{\mathrm{C}} 31.4\left(\mathrm{C}-3^{\prime}\right), \delta_{\mathrm{C}} 28.8\left(\mathrm{C}-4^{\prime}\right), \delta_{\mathrm{C}} 22.4\left(\mathrm{C}-5^{\prime}\right)$, $\delta_{\mathrm{C}} 10.6\left(\mathrm{C}-6^{\prime}\right), \delta_{\mathrm{C}} 23.3\left(\mathrm{C}-7^{\prime}\right)$, and $\delta_{\mathrm{C}} 13.7\left(\mathrm{C}-8^{\prime}\right)$, on the basis of its spectral data compound 4 was identified as di-(2-ethylhexyl) phthalate [29, 30].

Compound 5 was obtained as fine powder $\left(R_{\mathrm{f}}\right.$ upon $\mathrm{PC}$ in $15 \% \mathrm{AcOH}[0.81])$. It showed a characteristic violet spot on PC, which indicated its phenolic nature. It showed a characteristic spectral data of poly-aromatic nucleus compounds. ${ }^{13} \mathrm{C}-\mathrm{NMR}$ spectrum showed presence of 31 carbon atoms. Two quinone carbonyl groups are deduced from two carbon signals appeared at $\delta_{\mathrm{C}} 189.0$ and $184.7 \mathrm{ppm}$. Aromatic carbons showed numerous signals at $\delta_{\mathrm{C}} 103.46-144.94 \mathrm{ppm}$, which proved poly-aromatic ring structures, supported by ${ }^{1} \mathrm{H}-\mathrm{NMR}$ spectral data at $\delta_{\mathrm{H}} 6.96$ and $6.61 \mathrm{ppm}$. Four methoxy groups attached to aromatic ring showed a characteristic signals at $\delta_{\mathrm{C}} 62.60,65.40,57.30$, and $55.9 \mathrm{ppm}$ in ${ }^{13} \mathrm{C}-\mathrm{NMR}$ spectrum and four singlets at $\delta_{\mathrm{H}} 3.88$, 3.76, 3.67, and $3.63 \mathrm{ppm}$ in ${ }^{1} \mathrm{H}-\mathrm{NMR}$ spectrum. Moreover, the presence of $\mathrm{OH}$ signal at $\delta_{\mathrm{H}} 12.94 \mathrm{ppm}$ indicated presence of phenolic hydroxyl group. Also, the carbon signal appeared at $\delta_{\mathrm{C}} 168.09 \mathrm{ppm}$ suggested the presence of unsaturated lactone structure of methylated isocoumarine moiety. Four methine (-CH-) groups showed characteristic signals at $\delta_{\mathrm{C}} 120.6,108.5$, 107.2 , and $103.4 \mathrm{ppm}$. Two methylene groups appeared at $\delta_{\mathrm{C}} 21.83 \& 28.94 \mathrm{ppm}$ and $\delta_{\mathrm{C}} 2.7-2.8 \& 2.4-2.5 \mathrm{ppm}$ in ${ }^{1} \mathrm{H}-\mathrm{NMR}$ spectrum. Furthermore, the carboxylic carbon attached to aromatic ring gave a signal at $173.5 \mathrm{ppm}$ in ${ }^{13} \mathrm{C}-\mathrm{NMR}$ spectrum. These spectral data were compared to that of polyketide compounds, i.e., griseorhodin A, collinone, precollinone, pradimicine lactone, polyketide KS-619-1, and anthraquinone compounds; it showed high similarities to these compounds [31]. Therefore, compound 5 could be identified as 2,4,5,17-tetramethoxy pradimicin lactone.

Compound 6 was obtained as orange powder $\left(R_{\mathrm{f}}\right.$ upon PC in $15 \% \mathrm{AcOH}[0.14])$. Chemical and physical data suggested that compound 6 is coumarin glycoside. The chemical structure of the compound was interpreted via ${ }^{1} \mathrm{H}-\mathrm{NMR}$ analysis. It showed three aromatic singlet signals at $\delta_{\mathrm{H}} 7.38,7.06$, and $6.66 \mathrm{ppm}$ attributed to $\mathrm{H}-4, \mathrm{H}-6$, and $\mathrm{H}-8$, respectively. It also showed singlet at $\delta_{\mathrm{H}} 13.62 \mathrm{ppm}$ characteristic to aromatic hydroxyl proton. The anomeric proton appears as doublet at $\delta_{\mathrm{H}} 4.13 \mathrm{ppm}$ (d, $\left.J=5.7 \mathrm{~Hz}, \mathrm{H}-1 \mathrm{Rha}\right)$. It showed also a characteristic rhamnose methyl at $\delta_{\mathrm{C}} 1.21 \mathrm{ppm}$. Therefore, compound 6 could be identified as 3,5-dihydroxy-7-O- $\alpha$-rhamnopyranoyl- $2 H$ chromen-2-one [32].

Compound 7 was obtained as pale yellow fine crystal (m.p. 264-266; $R_{\mathrm{f}}$ upon PC in 15\% AcOH [0.75]). It showed a characteristic yellow spot on PC. In the ${ }^{1} \mathrm{H}-\mathrm{NMR}$ spectrum two meta coupled aromatic protons at $\delta_{\mathrm{H}} 8.21 \mathrm{ppm}(\mathrm{d})$ and $9.10 \mathrm{ppm}$ (brs) were appeared in addition to three aromatic protons at $\delta_{\mathrm{H}}$ $7.42,7.63$, and $7.80 \mathrm{ppm}$, which indicate the aromatic nature of the compound (Table 3 ). ${ }^{13} \mathrm{C}-\mathrm{NMR}$ spectrum showed two quinone $(-\mathrm{C}=\mathrm{O})$ groups at $\delta_{\mathrm{C}} 187.1$ and $197.1 \mathrm{ppm}$, in addition to carboxylic group at $\delta_{\mathrm{C}} 166.7$ and acetate group signal at $\delta_{\mathrm{C}}$ $170.7 \mathrm{ppm}$. EtO- group was observed at $\delta_{\mathrm{H}} 0.80 \mathrm{ppm}(\mathrm{d}, J=$ $7.5 \mathrm{~Hz})$ and $\delta_{\mathrm{H}} 4.36(\mathrm{~d}, J=6.6 \mathrm{~Hz})$. Moreover, long-range correlation from $\delta_{\mathrm{H}} 4.36$ to 170.70 was observed. Three anomeric carbons were observed at ${ }^{13} \mathrm{C}$-NMR spectrum at $\delta_{\mathrm{C}} 94.4,92.6$, and $91.4 \mathrm{ppm}$ indicating the glycosidic nature of the compound. The oxymethine and methylene signals appeared between $\delta_{\mathrm{H}}$ $3.0-5.45 \mathrm{ppm}$ suggested the presence of glycosidic side chain attached to carbon- 5 through $O$-linkage indicated by a characteristic signal at $\delta_{\mathrm{C}} 128.5$ in ${ }^{13} \mathrm{C}-\mathrm{NMR}$ and $\mathrm{HMBC}$ spectrums. Also, ${ }^{1} \mathrm{H}-\mathrm{NMR}$ revealed many overlapping methyl and methylene signals in the up field region at $\delta_{\mathrm{H}} 2.6-0.80 \mathrm{ppm}$ and at $\delta_{\mathrm{C}} 94.4-43.6 \mathrm{ppm}$, the two signals at $\delta_{\mathrm{C}} 43.6$ and 44.6 indicating the presence of two carbons attached to nitrogen atom.

Table 3. HMBC assignments, ${ }^{1} \mathrm{H}(300 \mathrm{MHz})$ and ${ }^{13} \mathrm{C}(75 \mathrm{MHz}) \mathrm{NMR}$ spectral data of compound 7 in DMSO- $d_{6}(\delta$ in ppm)

\begin{tabular}{|c|c|c|c|}
\hline Position & $\delta_{\mathrm{C}} \mathrm{ppm}$ & $\delta_{\mathrm{H}} \mathrm{ppm}$ & HMBC \\
\hline \multicolumn{4}{|c|}{ Aglycone } \\
\hline 1 & 128.54 & & \\
\hline 2 & 133.90 & $8.21(\mathrm{~d})$ & \\
\hline 3 & 134.08 & & \\
\hline 4 & 129.10 & 9.1 (brs) & \\
\hline $4 a$ & 130.40 & & \\
\hline 5 & 128.45 & & \\
\hline 6 & 127.80 & 7.42 & \\
\hline 7 & - & 7.62 & \\
\hline 8 & 120.75 & 7.8 & \\
\hline $8 \mathrm{a}$ & 131.63 & & \\
\hline 9 & 187.14 & & \\
\hline $9 a$ & 133.58 & & \\
\hline 10 & 197.14 & & \\
\hline $10 \mathrm{a}$ & 111.8 & & \\
\hline \multicolumn{4}{|c|}{ Sugar moieties } \\
\hline $1^{\prime}$ & 94.46 & 5.45 & $5,3^{\prime}$ \\
\hline $2^{\prime}$ & 29.2 & 2.4 & $4^{\prime}$ \\
\hline $3^{\prime}$ & 57.4 & - & $1^{\prime}, 5^{\prime}$ \\
\hline $4^{\prime}$ & 72.06 & 3.25 & $2^{\prime}, 6^{\prime}$ \\
\hline $5^{\prime}$ & 65.86 & 3.55 & $3^{\prime}$ \\
\hline $6^{\prime}$ & 20.55 & 1.66 & $4^{\prime}$ \\
\hline $3^{\prime}-\mathrm{N}\left(\mathrm{CH}_{3}\right)_{2}$ & $43.66 / 44.65$ & 2.17 & \\
\hline $1^{\prime \prime}$ & 92.65 & 4.92 & $4^{\prime}, 3^{\prime \prime}$ \\
\hline $2^{\prime \prime}$ & 24.65 & 1.9 & $4^{\prime \prime}$ \\
\hline 3" & 25.34 & - & $5^{\prime \prime}, 1^{\prime \prime}$ \\
\hline 4" & 75.11 & 3.17 & $2^{\prime \prime}, 6^{\prime \prime}$ \\
\hline $5^{\prime \prime}$ & 66.98 & 4.44 & $3^{\prime \prime}$ \\
\hline $6^{\prime \prime}$ & 22.2 & $1.9(\mathrm{~d}, 6.6)$ & $4 "$ \\
\hline $1^{\prime \prime \prime}$ & 91.42 & 5.15 & 4", 3"' \\
\hline $2^{\prime \prime \prime}$ & 28.71 & 1.6 & $4^{\prime \prime \prime}$ \\
\hline $3^{\prime \prime \prime}$ & 33.85 & 2.41 & $1^{\prime \prime \prime}, 5^{\prime \prime \prime}$ \\
\hline $4^{\prime \prime \prime}$ & - & 4.1 & $2^{\prime \prime \prime}, 6$ 6"' \\
\hline $5^{\prime \prime \prime}$ & 68.39 & $4.35(6.6)$ & $3^{\prime \prime \prime}$ \\
\hline $6^{\prime \prime \prime}$ & 14.23 & $1.20(5.1)$ & $4^{\prime \prime \prime}$ \\
\hline $3-\mathrm{COOH}$ & 166.79 & & \\
\hline EtOCO- & 170.70 & & \\
\hline$-\mathrm{CH}_{2}-$ & 65.8 & $4.36(\mathrm{~d}, J=6.6 \mathrm{~Hz})$ & \\
\hline$-\mathrm{CH}_{3}$ & 14.0 & $0.8(\mathrm{~d}, J=7.5 \mathrm{~Hz})$ & \\
\hline
\end{tabular}


Complete assignments and connectivities of the compound were determined from H-H COSY, HMQC (Heteronuclear MultipleQuantum Correlation), and HMBC spectra. By comparing ${ }^{1} \mathrm{H}-$ and ${ }^{13} \mathrm{C}-\mathrm{NMR}$ data with literature, it was shown that compound 7 is quinone connected to side chain at C-5 of three sugar moieties, viz., rhodosamine, 2-deoxy-D-glucose, and cinerulose B. Three anomeric proton signals were assigned at $\delta_{\mathrm{H}} 5.45 \mathrm{ppm}$ (rhodosamine), $4.92 \mathrm{ppm}$ (deoxy glucose), and $5.15 \mathrm{ppm}$ (cinerulose), in the ${ }^{1} \mathrm{H}-\mathrm{NMR}$ spectrum through their direct one bond coupling in the HMQC spectrum with their own anomeric carbon signals at $\delta_{\mathrm{C}} 94.4,92.6$, and $91.4 \mathrm{ppm}$, respectively. The interglycosidic and sugar aglycone linkages were deduced from the long-range three-bond HMBC correlations. The HMBC exhibited correlations between $\mathrm{H}-1^{\prime}\left[\delta_{\mathrm{H}} 5.45\right.$ (rhodosamine) $]$ and $\mathrm{C}-5\left[\left(\delta_{\mathrm{C}} 128.4\right)\right.$ aglycone $], \mathrm{H}-1 "$ [ $\left(\delta_{\mathrm{H}} 4.92\right)$ deoxy glucose $]$ and $\mathrm{C}-4^{\prime}\left[\left(\delta_{\mathrm{C}} 72.06\right)\right.$ rhodosamine $]$, and $\mathrm{H} 1$ "' $\left[\left(\delta_{\mathrm{H}} 5.15\right)\right.$ cinerulose $]$ and $\mathrm{C}-4$ " $\left[\left(\delta_{\mathrm{C}}\right.\right.$ 75.11) deoxy glucose (Table 3). All ${ }^{1} \mathrm{H}$ - and ${ }^{13} \mathrm{C}$-resonances were assigned with the aid of $\mathrm{HMQC}$ and $\mathrm{HMBC}$ correlation peaks and comparison with the corresponding data of structurally related compounds [33]. Accordingly, compound 7 was identified as Juglanthraquinone A-5-O-rhodosamine$\left(4^{\prime} \rightarrow 1^{\prime \prime}\right)$-2-deoxy-D-glucose $\left(4^{\prime \prime} \rightarrow 1^{\prime \prime \prime}\right)$-cinerulose B.

Compound 8 was obtained as colorless amorphous solid $\left(R_{\mathrm{f}}\right.$ upon PC in 15\% AcOH [0.9]; UV [MeOH] $280 \mathrm{~nm})$. Both ${ }^{1} \mathrm{H}$ and ${ }^{13} \mathrm{C}$ spectra (DMSO- $d_{6}$ ) showed a characteristic signals for peptide nucleus. ${ }^{13} \mathrm{C}$-NMR spectrum showed nine signals for the amide carbonyl at $\delta_{\mathrm{C}} 173.5,173.3,173.0,170.4$, $169.0,166.4,165.3,156.3$, and $156.1 \mathrm{ppm}$. Resonances present in the aromatic region of ${ }^{13} \mathrm{C}-\mathrm{NMR}$ at $\delta_{\mathrm{C}} 136.8,130.2$, $128.8,127.1,128.3$, and $129.1 \mathrm{ppm}$, supporting the presence of phenyl alanine moiety, and also resonances at $\delta_{\mathrm{C}} 128.1$, $130.7,114.9,156.1,114.9$, and $130.3 \mathrm{ppm}$, suggesting the presence of tyrosin moiety. These data are in agreement with ${ }^{1} \mathrm{H}-\mathrm{NMR}$ spectra at $\delta_{\mathrm{H}} 7.43-6.37 \mathrm{ppm}$. Moreover, butyric acid side chain was identified by methyl triplet at $\delta_{\mathrm{H}} 0.87$ and $\delta_{\mathrm{C}} 14.0 \mathrm{ppm}$. Compound 8 was also recognized by presence of 3-amino-6-hydroxy-2-piperdone (Ahp) moiety $(-\mathrm{C}=\mathrm{O})$ at $\delta_{\mathrm{C}} 169.0$ and $-\mathrm{CH}_{2}-\mathrm{OH}$ at $\delta_{\mathrm{C}} 71.8 \mathrm{ppm}$. Therefore, compound 8 was identified as micropeptin via comparison its spectral and physical data with that of literature [34].

In vitro Antimicrobial Activity of Compound 7. Compound 7 showed a moderate in vitro antimicrobial activity against three pathogenic strains including $S$. aureus, $P$. aeruginosa, and

Table 4. In vitro antimicrobial activity of compound $7(50 \mu \mathrm{g} / \mathrm{disc})$ against four pathogenic microbial strains, compared to neomycin as a positive control

\begin{tabular}{lcc}
\hline Test microbe & \multicolumn{2}{c}{ Clear zone $(\phi \mathrm{mm})^{a}$} \\
\cline { 2 - 3 } & Compound 7 & Neomycin $^{c}$ \\
\hline S. aureus & $9.0 \pm 1.0^{b}$ & $14.0 \pm 1.0$ \\
P. aeruginosa & $10.0 \pm 1.0$ & $17.3 \pm 0.57$ \\
C. albicans & $10.66 \pm 1.15$ & $19.0 \pm 1.0$ \\
A. niger & $0-0$ & $0-0$ \\
$\quad{ }^{a}$ Inhibition zones diameter $(\mathrm{mm})$. & \\
${ }^{b}$ Mean $\pm \mathrm{SD}, n=2$. & \\
${ }^{c}$ Neomycin was used as a positive control $(50 \mu \mathrm{g} / \mathrm{disc})$. \\
\hline
\end{tabular}

C. albicans with inhibition zones values ranging from 9.0 to $10.66 \mathrm{~mm}$, compared to neomycin as a positive control with inhibition zones values ranging from 14.0 to $19.0 \mathrm{~mm}$ (Table 4 and Figure 4).

Literature review revealed that the in vitro antifungal activities of sixteen pure isolates from A. fumigatus were evaluated against $B$. cinerea, A. solani, A. alternata, C. gloeosporioides, $F$. solani, $F$. oxysporum f. sp. niveum, $F$. oxysporum f. sp. vasinfectum, and G. saubinettii, with minimum inhibitory concentration (MIC) values of $6.25-50 \mu \mathrm{g} / \mathrm{mL}$ [35]. Moreover, the antibacterial and antifungal activities of some isolates (asperfumoid, fumigaclavine $\mathrm{C}$, fumigaclavine $\mathrm{E}$, fumigaclavine $\mathrm{G}$, 3b-hydroxy-5a,8a-epidioxy-ergosta-6,22-diene, monomethylsulochrin, ergosterol, fumitremorgin $\mathrm{C}$, and helvolic acid) from A. fumigatus were evaluated against C. albicans, P. anaerobius, B. distasonis, E. coli, H. pylori, S. aureus, and others [36].

\section{Conclusions}

Fungi play an essential role in the production of several bioactive secondary metabolites. Fungal strain (3T) was isolated from the Egyptian local agricultural soil and was tested for its ability to produce bioactive metabolites by cultivating it on solid rice medium. The produced bioactive extract was fractionated using VLC (13 fraction), and the produced fractions were biologically evaluated by measuring their antimicrobial activities. The highly bioactive fractions (3-6) were further purified via using the Sephadex LH-20 column. One bioactive compound, Juglanthraquinone A-5-O-D-rhodosamine$\left(4^{\prime} \rightarrow 1^{\prime \prime}\right)$-2-deoxy-D-glucose $\left(4^{\prime \prime} \rightarrow 1^{\prime \prime \prime}\right)$-cinerulose $\mathrm{B}$, and other seven compounds were elucidated and characterized.

\section{Conflicts of Interest}

The authors declare no conflict of interest.

Acknowledgments. This work was financially supported by the Commission of Research Projects-Theodor Bilharz Research Institute (No. 103A).

\section{References}

1. Verpoorte, R. Drug Dev. Today 1998, 3, 232

2. Berdy, J. J. Antibiot. (Tokyo) 2005, 58,1 .

3. Abad, M. J.; Ansuategu, I. M.; Bermejio, P. Arkivoc. 2007, 2, 116

4. Muhsin, T. M.; Al-Duboon, A. A.; Khalaf, K. T. Jordan J. Biol. Sci. 2011, $4,205$.

5. Adrio, J.; Demain, L.; Arnold, L. Int. Microbiol. 2003, 6, 191

6. Rodrigues, K. F.; Costa, G. L.; Carvalho, M. P., Epifanio, R. D. A. World J. Microbiol. Biotechnol. 2005, 21, 1617.

7. Arora, D. S.; Chandra, P.; Braz, P. J. Microbiol. 2010, 41, 465.

8. Archer, D. B. Curr. Opin. Biotechnol. 2000, 11, 478.

9. Abdel-Aziz, M. S.; Hezma, A. M. Polym.-Plast. Technol. Eng. 2013, 52,1503 .

10. Collins, C. H.; Lyne, P. M. Microbiological Methods, 5th edition; Butterworth \& Co. Pub. Ltd.: London, UK \& Toronto, Canada, 1985.

11. Abdel-Aziz, M. S.; Abou-El-Sherbini, K. S.; Hamzawy, E. M. A.; Amr,

M. H. A.; El-Dafrawy, S. Appl. Biochem. Biotechnol. 2015, 176, 2225.

12. Zhao, G. Z.; Liu, X. Z.; Wu, W. P. Fungal Diver. 2007, 26, 313.

13. Raper, K. B.; Fennell, D. I. The genus Aspergillus; Williams and Williams: Baltimore, Washington, 1965.

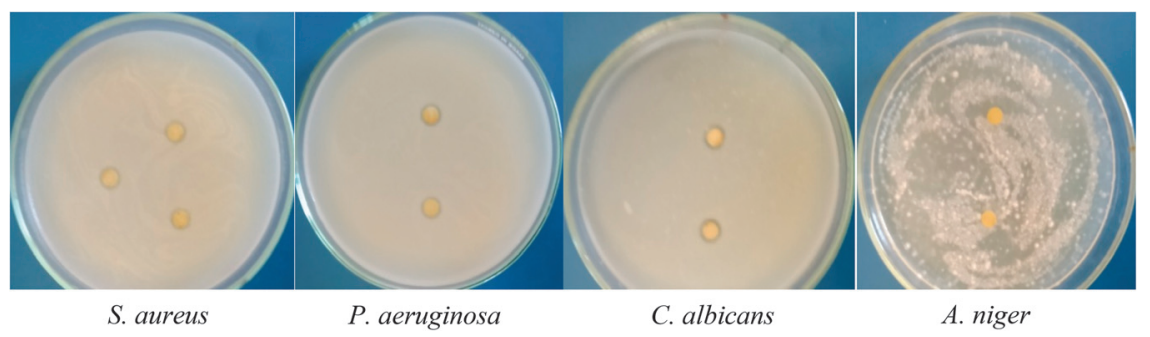

Figure 4. In vitro antimicrobial activity of compound 7 against four pathogenic microbial test strains 
14. Zhao, J.; Kong, F.; Li, R.; Wang, X.; Wan, Z.; Wang, D. J. Clin. Microbiol. 2001, 39, 2261.

15. Chen, Y. C. J. D.; Eisner, M. M.; Kattar, S. L.; Lafe, R. K.; Bui, U. J. Clin. Microbiol. 2001, 39, 4042.

16. White, N. A.; Dehal, P. K.; Duncan, J. M.; Williams, N. A.; Gartland, J. S.; Palfreyman, J. W.; Cooke, D. E. L. Mycol. Res. 2001, 105, 447.

17. Shaaban, M.; Nasr, H.; Hassan, A. Z.; Asker, M. S. Rev. Latinoamer Quim. 2013, 41, 50.

18. Rekha, M. K. R.; Manzur, A. P. P.; Sapna, K.; Abraham, M.; Preethi, G. U.;

Sarita, G. B.; Elyas, K. K. Curr. Res. Microbiol. Biotechnol. 2014, 2, 530.

19. Der Satyender, K. Y. Pharm. Chem. 2013, 5, 59

20. Zhao, J. L.; Liu, P.; Duan, J. A.; Qian, Y. F. China Tradit. Herb. Drugs

2013, 44, 1245

21. Bian-Na, S.; He-Ding, S.; Hong-Xi, W.; Li-Xiang, Y.; Zhi-Qing, C.; Ya, D. Trop. J. Pharm. Res 2014, 13, 2071.

22. Batchelor, J. G.; Cushley, R. J.; Prestegard, J. H. J. Org. Chem. 1974, $39,1698$.

23. Van, D. D. Phytochemical investigation of two Crassulaceae species: Rhodiola rosea L., the New "Herbal Stress Buster," and Sedum dasyphyllum L. [dissertation]; University of Genève: Genève, 2009.

24. Anke, H.; Ilham, K.; Zahner, H.; Laatsch, H. Arch. Microbiol. 1980, $126,223-230$
25. Engstrom, G. W.; McDorman, D. J.; Maroney, M. J. J. Agric. Food Chem. 1980, 28, 1139 .

26. Manojlovic, N. T.; Solujic, S.; Kristic, L. J. J. Serb. Chem. Soc. 2000, 65,555 .

27. Turner, W. B. Fungal Metabolites; Academic Press: New York, 1971.

28. Agarwal, S. K.; Singh, S. S.; Verma, S.; Kumar, S. J. Ethnopharmacol. 2000, 72, 43.

29. Dirar, A. I.; Mohamed, M. A.; Ahmed, W. J.; Mohammed, M. S.; Khalid, H. S.; Garelnabi, E. A. E. J. Pharmacogn. Phytochem. 2014, 3, 38

30. El-Sayed, O. H.; Asker, M. M. S.; Shash, S. M.; Hamed, S. R. Int. J. Chem. Tech. Res 2015, 8,58 .

31. Yunt, Z. S. Chemical investigation of Streptomyces albus heterologous expression strains and the biosynthesis of the aromatic polyketide griseorhodin [dissertation]; University of Bonn: İstanbul, Türkei, 2012.

32. Wang, M.; Zhoo, J.; Hung, R.; Li, G.; Zeug, X.; Li, X. Nat. Prod. Res. 2016, 30, 1796

33. Shimasaka, A.; Hawakwa, Y.; Nakagawa, M.; Furihata, K.; Seto, H.; Otake, N. J. Antibiot. 1987, 40, 116.

34. Belofsky, G. N.; James, B. G.; Donald, T. W.; Patrick, F. D. Tetrahedron Lett. 1998, 39, 5497.

35. Li, X.; Zhang, Q.; Zhang, A.; Gao, J. J. Agric. Food Chem. 2012, 60, 3424 36. Zhang, H.; Tang, Y.; Ruan, C.; Bai, X. Rec. Nat. Prod. 2016, 10, 1. 